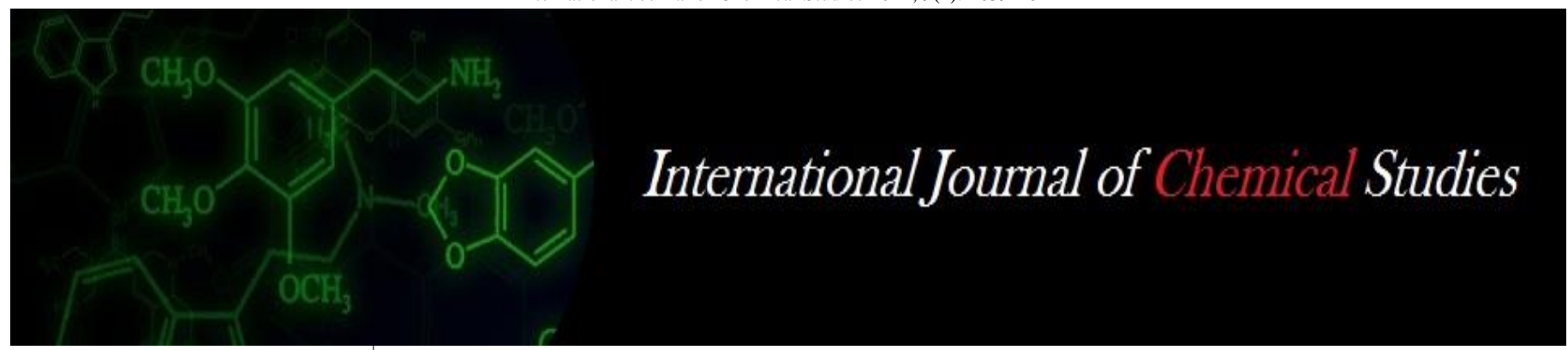

P-ISSN: 2349-8528

E-ISSN: 2321-4902

www.chemijournal.com

IJCS 2021; 9(1): 2639-2642

(C) 2021 IJCS

Received: 02-11-2020

Accepted: 12-12-2020

\section{Suresh Meena}

Department of Plant Pathology, Sri Karan Narendra Agriculture University, Jobner, Jaipur,

Rajasthan, India

RP Ghasolia

Department of Plant Pathology, Sri Karan Narendra Agriculture University, Jobner, Jaipur,

Rajasthan, India

\section{Jitendra Sharma}

Department of Plant Pathology, Sri Karan Narendra Agriculture University, Jobner, Jaipur, Rajasthan, India

\section{Shankar Lal Yaday}

Department of Plant Pathology, Sri Karan Narendra Agriculture University, Jobner, Jaipur,

Rajasthan, India
Corresponding Author: Suresh Meena

Department of Plant Pathology, Sri Karan Narendra Agriculture University, Jobner, Jaipur, Rajasthan, India

\section{Effect of weather parameters on the development of Alternaria blight of fennel incited by Alternaria alternata (Fr.) Keissler}

\author{
Suresh Meena, RP Ghasolia, Jitendra Sharma and Shankar Lal Yadav
}

DOI: https://doi.org/10.22271/chemi.2021.v9.i1ak.11625

\begin{abstract}
Diseases and pests are the important constraint in the production of fennel. An experiment was conducted at the Agronomy Farm, S.K.N. College of Agriculture, Jobner during rabi 2013-14 and 2014-15 to investigate the role of weather conditions like humidity, temperature, rainfall and sunshine on this diseases development. The first visible symptoms of disease first appeared during first week of February, became conspicuous from second week of February to second week of March and declined by the third week of March. The maximum development of Alternaria blight was favoured by a mean temperature ranging between 10.6 to $27.8^{\circ} \mathrm{C}$ and 10 to $27.1{ }^{\circ} \mathrm{C}$ along with an average relative humidity $58.5 \%$ and $51.5 \%$ of more than $70 \%$ during during rabi 2013-14 and 2014-15 respectively. The results of two consecutive cropping seasons with respect to weather parameters revealed that Alternaria blight of fennel is greatly favoured by relative humidity more than $80 \%$ and rainfall. A significant and positive correlation was recorded with morning and evening relative humidity whereas a negative non-significant correlation with maximum and minimum temperature during 2013-14 while negative significant correlation was obtained with maximum and minimum temperature during 2014-15.
\end{abstract}

Keywords: Weather, parameters, Alternaria blight, Keissler

\section{Introduction}

India is rightly known as the land of spices. It is the largest producer, consumer and exporter of spices in the world. A wide variety of spices are grown in the country, of which seed spices is a group. Seed spices include all those annuals whose dried seeds are used as spices like fennel, fenugreek, coriander and cumin. Seed spices are very important in human health and have a crucial role in Indian cuisine. Fennel (Foeniculum vulgare Mill.) belongs to the family Apiaceae. In India, the seeds are also used for mastication and chewing either alone or with betel leaves (Lakshman, 1952 and Agarwal et al., 2001) ${ }^{[1,2]}$. The main constituents of the fennel oil are anethole and fenchone. The other constituents are methyl chavicol, alpha-pinene, camphene, alpha-phellandrene and dipentene. The volatile oil, extracted from seeds is used for scenting soaps and flavouring cakes (Stanley Redgrove, 1933) ${ }^{[3]}$.

It is cultivated throughout the temperate and subtropical region in the world. Almost all seed spices are cultivated in India and has got the privilege to be called as the largest seed spices producing country in the world (Anonymous, 2013-14) ${ }^{[4]}$.

In Rajasthan, it is mainly cultivated in the districts of Sirohi, Jodhpur, Nagour, Tonk, Dausa and Pali and to a limited extent in Bharatpur, Kota and Ajmer. Fennel is attacked by a number of diseases viz., Ramularia blight (Ramularia foeniculi), powdery mildew (Leveillula taurica), seedling damping off (Alternaria petroselini), root rot (Fusarium solani), Alternaria blight (Alternaria alternata and Alternaria petroselini). Alternaria blight of fennel caused by Alternaria alternata is a serious bottleneck in augmenting fennel (Foeniculum vulgare) production in Gujarat (Chaudhari and Patel, 1987) ${ }^{[5]}$. It causes losses of different magnitudes. More than $50 \%$ of the inspected fields showed Alternaria blight symptoms on fennel with an incidence ranging from 30 to $100 \%$ in Italy (Infantino et al., 2009) ${ }^{[6]}$. A very little work has been done on epidemiological studies of this disease. Therefore the present investigation was initiated on some of such neglected but important aspects of this disease. The epidemiological studies on Alternaria blight of fennel will give an idea about the relationship of weather parameters for disease occurrence, survival and dissemination of the pathogen in nature. 
These studies will also help for devising forecasting systems and to develop an appropriate model for predication of the disease.

\section{Material and Methods}

\section{Collection, isolation and identification of the pathogen}

Infected plants of fennel were collected from farmer's field and isolations were made from the infected plants showing typical symptoms of Alternaria blight on potato dextrose agar (PDA) medium and culture purified by single spore technique. For further confirmation or identity of the fungus, the culture was sent to ITCC, Division of Plant Pathology, IARI, New Delhi and identified as Alternaria alternata with I. D. No. 9256.13.

\section{Effect of environmental factors on disease development}

The field experiments were conducted for two consecutive years (2013-14 and 2014-15) during rabi season at Agronomy Farm, S.K.N. College of Agriculture, Jobner with susceptible local cultivar of fennel. Cumulative disease progression from initiation and at intervals of 7 days was recorded. Weather variables viz., temperature, relative humidity, sunshine hours, rainfall etc. were also recorded for two cropping seasons and correlation among factors $\&$ disease development was worked out. The disease progression was recorded in the field. Sowing was done in the last week of October in the same filed in both the years. Average intensity of the disease was recorded on 100 tagged plants (4 replication, 25 plants per replicate) throughout the season in the field.

Per cent disease intensity (PDI) was calculated from initiation of the disease till the maturity of the crop as per following formula of Wheeler (1969) ${ }^{[7]}$ at 15 days intervals.

Weekly meteorological data on maximum and minimum temperature, morning and evening relative humidity, rainfall and duration of sun shine hours were obtained for the period between two consecutive disease recordings to establish their correlation with disease development.

Angular transformed values of per cent data were subjected to correlation and regression coefficient. The prediction equation used was $Y=a+b_{1} x_{1}+b_{2} x_{2}+\ldots+b_{6} x_{6}$ where $Y=$ predicted disease intensity, $a=$ Intercept, $b_{1}$ to $b_{6}=$ Regression coefficients, $\mathrm{x}_{1}$ to $\mathrm{x}_{6}=$ Minimum temperature $\left({ }^{\circ} \mathrm{c}\right), \mathrm{x}_{3}=$ Morning relative humidity, $\mathrm{x}_{4}=$ Evening relative humidity, $\mathrm{x}_{5}=$ Rainfall $(\mathrm{mm})$ and $\mathrm{x}_{6}=$ Duration of sunshine (hrs/day). The information obtained from these observations was studied in relation to weather factors viz., minimum and maximum temperature, rainfall, and relative humidity prevailed during the crop period by following standard statistical methods.

Table 1: Disease rating scale for blight of fennel

\begin{tabular}{|c|c|c|}
\hline S. No & Description & Grade \\
\hline 1 & No incidence/ Healthy & 0 \\
\hline 2 & Symptoms on leaf tip and leaves only & 1 \\
\hline 3 & Symptoms on leaves and petiole & 2 \\
\hline 4 & Symptoms on leaves, petiole and stem & 3 \\
\hline 5 & Symptoms on leaves, petiole stem and inflorescence & 4 \\
\hline 6 & Symptoms on leaves, stem, inflorescence including & 5 \\
\hline & Seed & \\
\hline
\end{tabular}

PDI

Sum of numerical disease rating

No. of plants assessed $\mathrm{x}$ Maximum disease rating

\section{Results and Discussions}

Effect of environmental factors (temperature, relative humidity and rainfall) on the development of Alternaria blight of fennel was studied in rabi 2013-14 and 2014-15 (Table 2). This disease first appeared during first week of February, became conspicuous from second week of February to second week of March and declined by the third week of March. The occurrence of disease in term of per cent disease intensity in relation to weather variable was analysed statistically by using stepwise multiple regression analysis. Correlation coefficient of per cent disease intensity with meteorological factors was worked out and regression equation was formulated.

Correlation analysis of per cent disease intensity with weather parameters was indicated that maximum (higher than $18.2{ }^{\circ} \mathrm{C}$ ) and minimum (less than $2.3{ }^{\circ} \mathrm{C}$ ) temperature had negative non-significant correlation during 2013-14 and negative significant correlation in 2014-15, while morning (48-93\%) and evening (13-73\%) relative humidity had positive significant correlation during both the years. However, statistically analysis between rainfall and disease intensity showed positive correlation but non-significant during 201314 and 2014-15. Effect of sunshine hours on disease intensity showed negative and significant correlation in 2013-14 and negative but non-significant correlation in the year 2014-15 (Table 3).

A multiple correlation between the dependent variable (disease intensity) and a group of other six independent variables (weather parameters) was responsible for the disease development in both the cropping season under study. The coefficient of multiple determinations $\left(\mathrm{R}^{2}\right)$ was 63.30 and 75.50 per cent during 2013-14 and 2014-15, respectively, which means that 63.30 to 75.50 per cent disease intensity was depend on the meteorological factors taken into consideration during both the cropping season (Table 4).

The analysis of all the six independent variables individually and in combinations that fit analysis best revealed that each weather factor played an important role in disease development in addition to other unknown factors.

The results of two consecutive cropping seasons with respect to weather parameters revealed that Alternaria blight of fennel is greatly favoured by relative humidity more than $80 \%$ and rainfall.

Significant and positive correlation was recorded with morning and evening relative humidity whereas a negative non-significant correlation with maximum and minimum temperature during 2013-14 while negative significant correlation was obtained with maximum and minimum temperature during 2014-15. This finding is supported with results obtained by earlier workers. Gemawat and Prasad (1971) ${ }^{[8]}$ has also reported that high humidity $(90 \%$ and above) for about 3 days and temperature between $23-28{ }^{0} \mathrm{C}$ and rainfall,

Sunshine hours and wind speed play important role in the development of cumin blight caused by A. burnsii. Sharma and Pandey (2013) [9] has also noted that maximum temperature between $29-35.5{ }^{\circ} \mathrm{C}$, minimum temperature between $9.6-19.7{ }^{\circ} \mathrm{C}$, average relative humidity of more than 60 per cent in the morning and more than 28 per cent in afternoon, wind speed 2.1-4.8 $\mathrm{km} / \mathrm{hr}$ and bright sunshine hours favourable for development of blight of cumin. Singh and Shukla (1986) ${ }^{[10]}$ pointed out that Alternaria alternata is favoured by temperature of $28.7{ }^{\circ} \mathrm{C}$ to $32.2^{\circ} \mathrm{C}$ and relative humidity of 74 per cent. 
Table 2: Percent disease intensity of fennel in relation to environmental factors

\begin{tabular}{|c|c|c|c|c|c|c|c|c|c|c|c|c|c|c|}
\hline \multirow{3}{*}{$\begin{array}{l}\text { Meteorological } \\
\text { week }\end{array}$} & \multicolumn{7}{|c|}{ 2013-14 } & \multicolumn{7}{|c|}{ 2014-15 } \\
\hline & \multicolumn{2}{|c|}{$\begin{array}{c}\text { Temperature } \\
\left({ }^{\circ} \mathrm{C}\right)\end{array}$} & \multicolumn{2}{|c|}{$\begin{array}{c}\text { Relative } \\
\text { Humidity }(\%)\end{array}$} & \multirow{2}{*}{$\underset{(\mathbf{m m})}{\text { Rainfall }}$} & \multirow{2}{*}{$\begin{array}{c}\text { Sunshine } \\
\text { (hr/day) }\end{array}$} & \multirow{2}{*}{$\begin{array}{c}\text { Percent } \\
\text { Disease } \\
\text { intensity }\end{array}$} & \multicolumn{2}{|c|}{$\begin{array}{c}\text { Temperature } \\
\left({ }^{\circ} \mathrm{C}\right)\end{array}$} & \multicolumn{2}{|c|}{$\begin{array}{c}\text { Relative } \\
\text { Humidity }(\%)\end{array}$} & \multirow{2}{*}{$\begin{array}{c}\text { Rainfall } \\
(\mathrm{mm})\end{array}$} & \multirow{2}{*}{$\begin{array}{c}\text { Sunshine } \\
\text { (hr/day) }\end{array}$} & \multirow{2}{*}{$\begin{array}{c}\text { Percent } \\
\text { Disease } \\
\text { intensity }\end{array}$} \\
\hline & Max. & Min. & Mor. & Min. & & & & Max. & Min. & Mor. & Min. & & & \\
\hline $31 / 12(52)$ & 19.5 & 4.8 & 88 & 41 & 0 & 6.2 & 00 & 22.7 & 2.4 & 91 & 36 & 0 & 8.9 & 0.00 \\
\hline $07 / 01(01)$ & 20.1 & 2.3 & 90 & 36 & 0 & 4.9 & 0.00 & 20.9 & 6.6 & 91 & 51 & 0 & 4 & 0.00 \\
\hline $14 / 01(02)$ & 20.1 & 3.7 & 88 & 40 & 0 & 6.5 & 0.00 & 24.4 & 3.9 & 83 & 36 & 0 & 8.9 & 0.00 \\
\hline $21 / 01(03)$ & 19.4 & 4.9 & 93 & 59 & 7.8 & 4.6 & 0.00 & 21.1 & 4.9 & 85 & 43 & 0 & 7.5 & 0.00 \\
\hline 28/01(04) & 18.5 & 10.4 & 90 & 63 & 6 & 5.5 & 0.00 & 18.2 & 9.5 & 91 & 73 & 10.2 & 3.1 & 0.00 \\
\hline $04 / 02(05)$ & 22.3 & 8.3 & 84 & 36 & 0 & 7.6 & 0.00 & 23 & 6.3 & 82 & 34 & 0 & 9.5 & 0.00 \\
\hline $11 / 02(06)$ & 23.9 & 6.6 & 85 & 35 & 0 & 7.6 & 4.25 & 23.9 & 7.3 & 83 & 35 & 0 & 9.5 & 6.32 \\
\hline $18 / 02(07)$ & 22 & 5.6 & 87 & 36 & 0 & 8.4 & 1.55 & 27.8 & 10 & 78 & 33 & 0 & 9 & 3.68 \\
\hline $25 / 02(08)$ & 24.1 & 9.4 & 86 & 29 & 0 & 7.4 & 6.20 & 31.1 & 12.7 & 77 & 34 & 0 & 9 & 5.00 \\
\hline $04 / 03(09)$ & 24.6 & 10.1 & 93 & 42 & 13.6 & 5 & 13.25 & 25.3 & 11 & 84 & 43 & 14 & 5.5 & 16.00 \\
\hline $11 / 03(10)$ & 27.8 & 10.6 & 83 & 34 & 0 & 7.9 & 22.75 & 27.1 & 10 & 78 & 25 & 0 & 8.9 & 26.48 \\
\hline $18 / 03(11)$ & 30.1 & 12.7 & 82 & 26 & 4.8 & 6.1 & 16.23 & 24.9 & 13.4 & 82 & 54 & 18.2 & 4.8 & 18.18 \\
\hline $25 / 03(12)$ & 32.1 & 14.2 & 80 & 29 & 9.6 & 8.3 & 8.02 & 31.3 & 15.1 & 65 & 38 & 0 & 8.9 & 3.67 \\
\hline $01 / 04(13)$ & 32.2 & 16.3 & 63 & 31 & 0 & 7.9 & 4.97 & 35.5 & 18.7 & 67 & 30 & 0 & 7.5 & 0.95 \\
\hline $08 / 04(14)$ & 35.1 & 13.8 & 64 & 24 & 0 & 9.4 & 1.90 & 31.9 & 18.4 & 84 & 39 & 12.2 & 6.5 & 0.72 \\
\hline $15 / 4(15)$ & 35.9 & 15.5 & 55 & 26 & 0 & 9.3 & 1.63 & 32.3 & 17.2 & 84 & 41 & 15 & 6.6 & 1.66 \\
\hline 22/04 (16) & 31.8 & 14.4 & 74 & 35 & 5.8 & 7.8 & 1.10 & 37 & 19.7 & 64 & 26 & 0 & 9.3 & 0.34 \\
\hline $29 / 04(17)$ & 37.9 & 19.2 & 57 & 19 & 0 & 10.7 & 0.45 & 39.9 & 20.7 & 51 & 13 & 0 & 10.6 & 0.20 \\
\hline $06 / 05(18)$ & 40.6 & 22.1 & 55 & 21 & 0.06 & 9.6 & 0.00 & 40.8 & 20.6 & 48 & 16 & 0 & 10.9 & 0.00 \\
\hline
\end{tabular}

Table 3: Simple correlation of disease intensity with major meteorological factors

\begin{tabular}{|c|c|c|c|}
\hline Variable & & Year & Simple correlation \\
\hline \multirow{3}{*}{ Temperature } & \multirow{2}{*}{ Maximum } & $2013-14$ & -0.392 \\
\cline { 3 - 4 } & & $2014-15$ & $-0.682^{* *}$ \\
\cline { 3 - 4 } & \multirow{2}{*}{ Minimum } & $2013-14$ & -0.334 \\
\cline { 3 - 4 } & \multirow{3}{*}{ Melative humidity } & $2014-15$ & -0.630 \\
\cline { 3 - 4 } & \multirow{2}{*}{ Minimum } & $2013-14$ & $0.570^{*}$ \\
\cline { 3 - 4 } & & $2014-15$ & $0.458^{*}$ \\
\cline { 3 - 4 } & & $2013-14$ & 0.376 \\
\hline Rainfall & & $2014-15$ & 0.345 \\
\hline & & $2013-14$ & 0.334 \\
\hline Sunshine & & $2014-15$ & 0.285 \\
\hline & & $2013-14$ & $-0.627^{* *}$ \\
\hline
\end{tabular}

$* *$ Correlation is significant at $1 \% \mathrm{P}=0.01$

$*$ Correlation is significant at $5 \% \mathrm{P}=0.05$

Table 4: Prediction equation and $\mathrm{R}^{2}$ for predicating Alternaria blight disease intensity in fennel

\begin{tabular}{|c|c|c|c|c|c|c|c|}
\hline \multicolumn{7}{|c|}{ Multiple regression equation (2013-14) } & $\mathbf{R}^{2}$ \\
\hline$Y=20.679$ & $-0.469 \mathrm{X}_{1}(0.332)$ & & & & & & 0.153 \\
\hline 27.571 & $-0.980 \mathrm{X}_{1}(1.159)$ & $0.668 \mathrm{X}_{2}(1.447)$ & & & & & 0.171 \\
\hline-71.166 & $0.831 \mathrm{X}_{1}(1.348)$ & $0.165 \mathrm{X}_{2}(1.287)$ & $0.673 \mathrm{X}_{3}(0.331)$ & & & & 0.432 \\
\hline-72.074 & $0.851 \mathrm{X}_{1}(1.526)$ & $0.156 \mathrm{X}_{2}(1.386)$ & $0.671 \mathrm{X}_{3}(0.354)$ & $0.018 \mathrm{X}_{4}(0.4930)$ & & & 0.432 \\
\hline-152.835 & $1.877 \mathrm{X}_{1}(1.797)$ & $0.450 \mathrm{X}_{2}(1.404)$ & $1.146 \mathrm{X}_{3}(0.569)$ & $0.441 \mathrm{X}_{4}(0.631)$ & $-0.887 \mathrm{X}_{5}(0.837)$ & & 0.510 \\
\hline-120.790 & $2.490 \mathrm{X}_{1}(1.735)$ & $-0.194 \mathrm{X}_{2}(1.389)$ & $1.005 \mathrm{X}_{3}(0.541)$ & $0.315 \mathrm{X}_{4}(0.597)$ & $-1.218 \mathrm{X}_{5}(0.817)$ & $-3.369 X_{6}(2.376)$ & 0.633 \\
\hline \multicolumn{7}{|c|}{ Multiple regression equation (2013-14) } & $\mathbf{R}^{2}$ \\
\hline$Y=38.644$ & $-1.025 \mathrm{X}_{1}(0.331)$ & & & & & & 0.466 \\
\hline 37.873 & $-0.957 \mathrm{X}_{1}(0.838)$ & $-0.093 \mathrm{X}_{2}(1.031)$ & & & & & 0.466 \\
\hline 93.017 & $-2.136 \mathrm{X}_{1}(1.329)$ & $0.527 \mathrm{X}_{2}(1.155)$ & $-0.376 \mathrm{X}_{3}(0.332)$ & & & & 0.533 \\
\hline 151.184 & $-4.496 \mathrm{X}_{1}(1.912)$ & $2.621 \mathrm{X}_{2}(1.682)$ & $-0.278 \mathrm{X}_{3}(0.312)$ & $-6.85 \mathrm{X}_{4}(0.4260)$ & & & 0.647 \\
\hline 144.841 & $-3.584 X_{1}(2.173)$ & $1.437 \mathrm{X}_{2}(2.136)$ & $-0.351 \mathrm{X}_{3}(0.325)$ & $-0.729 X_{4}(0.433)$ & $0.483 \mathrm{X}_{5}(0.527)$ & & 0.685 \\
\hline 175.984 & $-2.398 X_{1}(2.259)$ & $0.036 \mathrm{X}_{2}(2.298)$ & $-0.461 X_{3}(0.321)$ & $-0.880 \mathrm{X}_{4}(0.428)$ & $0.166 \mathrm{X}_{5}(0.557)$ & $-4.015 \mathrm{X}_{6}(3.064)$ & 0.755 \\
\hline
\end{tabular}

\section{References}

1. Lakshman G. Taxonomical studies of a few economic genera in umbelliferae. M.sc. Thesis, Madras University $1952,45$.

2. Agarwal S, Sastri EVD, Sharma RK. Seed Spices, Production Quality, Export 2001;1:109-114.

3. Stanley Redgrove HC. Spices and condiments. Sir Isaac Pitman and Sons Ltd. London 1933, 1-56.
4. Anonymous. Area and production of Arecanut and spices Directorate of Arecanut and spices Development. (Deptt. of Agriculture and Co-operation) Ministry of Agriculture, GOI, Calicut 2013-14, 67.

5. Chaudhari SM, Patel AJ. Chemical control of Alternaria blight and Ramularia blight of fennel (Foeniculum vulgare). Indian J Mycol. Pl. Pathol 1987;17(3):348-350.

6. Infantino A, Giambattista GDi, Pucci N, Pallottini L, Poletti F, Boccongelli C. First report of Alternaria 
petroselini on fennel in Italy. New Dis. Repts 2009;19:26.

7. Wheeler BEJ. An introduction to plant disease. John Wiley, London, U.K 1969, 301.

8. Gemawat PD, Prasad N. Epidemiological studies on Alternaria blight of Cuminum cyminum. Indian J Mycol. Pl. Pathol 1971;2:65-75.

9. Sharma S, Pandey RN. Survial, epiderminolgy and management of Alternata blight of cumin in Gujarat. Bioinfolet 2013;10(2B):639-642.

10. Singh M, Shukla TN. Epidemiology of Alternaria leaf spot and fruit rot of brinjal. Indian Phytopathology 1986;39:119-120. 